\title{
Üst ekstremite alçıları ve endikasyonları: önkol, el bilek, el seviyesi kırıklarına yönelik alçılar
}

\section{Upper extremity casting and indications: forearm, wrist, hand fractures}

\author{
Gökhun Arıcan ${ }^{1}$, Alper Öztürk ${ }^{2}$, Kadir Bahadır Alemdaroğlu \\ ${ }^{1}$ Ankara Eğitim ve Araştırma Hastanesi, Ortopedi ve Travmatoloji Kliniği, Ankara \\ ${ }^{2}$ Kızılcahamam Devlet Hastanesi, Ortopedi ve Travmatoloji Kliniği, Ankara
}

\begin{abstract}
Üst ekstremite yaralanmaları, genç erişkinlerde spor kazaları ve yaşlılarda basit düşme sonrası oldukça sık görülmektedir. Bu tip yaralanmalarda işlevsel sonuçlar, kemiğin durumu kadar çevresindeki yumuşak dokunun durumuna da bağlıdır. Uygun endikasyon içerisinde temel tedavi, alçı veya atel ile sık ve yakın takiptir. Alçılama uygulanırken dikkat edilmesi gereken temel ilkeler vardır. Bu derlemede, üst ekstremite alçıları ve endikasyonları ile alçılama sırasında ve sonrasında alınması gereken tedbirler sunulacaktır.
\end{abstract}

Anahtar sözcükler: üst ekstremite alçıları; radius distal uç kırıkları; önkol kırıkları; skafoid kırkları; boksör kırıları
Upper extremity injuries are quite common after sports accidents in young adults, and simple falls in the elderly. Functional outcomes in this type of injuries depend on the condition of the bone as well as the surrounding soft tissue. Within appropriate indications, basic treatment is casting or splint with frequent and close follow-up. There are basic principles to be aware of while casting. In this compilation, the upper limb casts, indications, and precautions to be taken during and after casting will be presented.

Key words: upper extremity casts; distal radius fracture; forearm fracture; scaphoid fracture; boxer fracture st ekstremite yaralanmaları, genç erişkinlerde spor kazaları ve yaşlılarda basit düşme sonrası oldukça sık görülmektedir. Çoğu üst ekstremite yaralanması, el ekstansiyondayken üzerine düşme ya da direkt travma nedeniyle olmaktadır. Özellikle sportif aktivitede el karakteristik olarak ön planda yer aldığı için, el ve el bileği yaralanmaları da sık görülmektedir. Üst ekstremite yaralanmalarını alt ekstremite yaralanmalarından ayıran temel fark ve üst ekstremite yaralanmalarında işlevsel sonuçlar, kemiğin durumu kadar yumuşak dokunun durumuna da bağlıdır. Üst ekstremite yaralanmalarında uygun endikasyon içerisinde temel tedavi, alçı veya atel ile sık ve yakın takiptir.

\section{TEMEL ILKELER}

Üst ekstremite alçı ve atel uygulamalarında dikkat edilmesi gereken temel ilkeler vardır. Bunlar;

\section{A. Önce zarar verme}

Öncelikle hastaya, alçı ile tedavinin neden gerektiği, tedavi olmaz ise karşılaşacağı komplikasyonlar ve alçı ile tedavi sırasında karşılaşılması muhtemel komplikasyonlar hakkında bilgi verilmeli, onamı alınmalıdır. Kötü yapılmış bir alçı; bası yaraları, sıkışıkıı nöropatisi, eklemlerde sertlik ve kompleks bölgesel ağrı sendromuna zemin hazırlayabilir. Bu yüzden, her alçı azami özen gösterilerek uygulanmalıdır. Alçı uygulamadan önce ekstremitenin fizik muayenesinin yapılması çok önemlidir; ödemli bir ekstremiteye asla çepeçevre alçı uygulanmamalıdır. Kırık redüksiyonu öncesi ve sonrası nörovasküler muayene mutlaka yapılmalı ve kayıt altına alınmalıdır.

\section{B. Alçının hangi eklemleri sabitleyeceğine karar vermek}

Kırık tiplerine göre değişmekle birlikte; genel olarak eklem içi veya ekleme yakın kırıklar için eklemden bir

- Illetişim adresi: Op. Dr. Gökhun Arıcan, Ankara Eğitim ve Araştırma Hastanesi, Altındağ, Ankara

Tel: 0312 -5903632 e-posta: gokhunarican@gmail.com

- Geliş tarihi: 1 Ağustos 2018 Kabul tarihi: 1 Ağustos 2018 


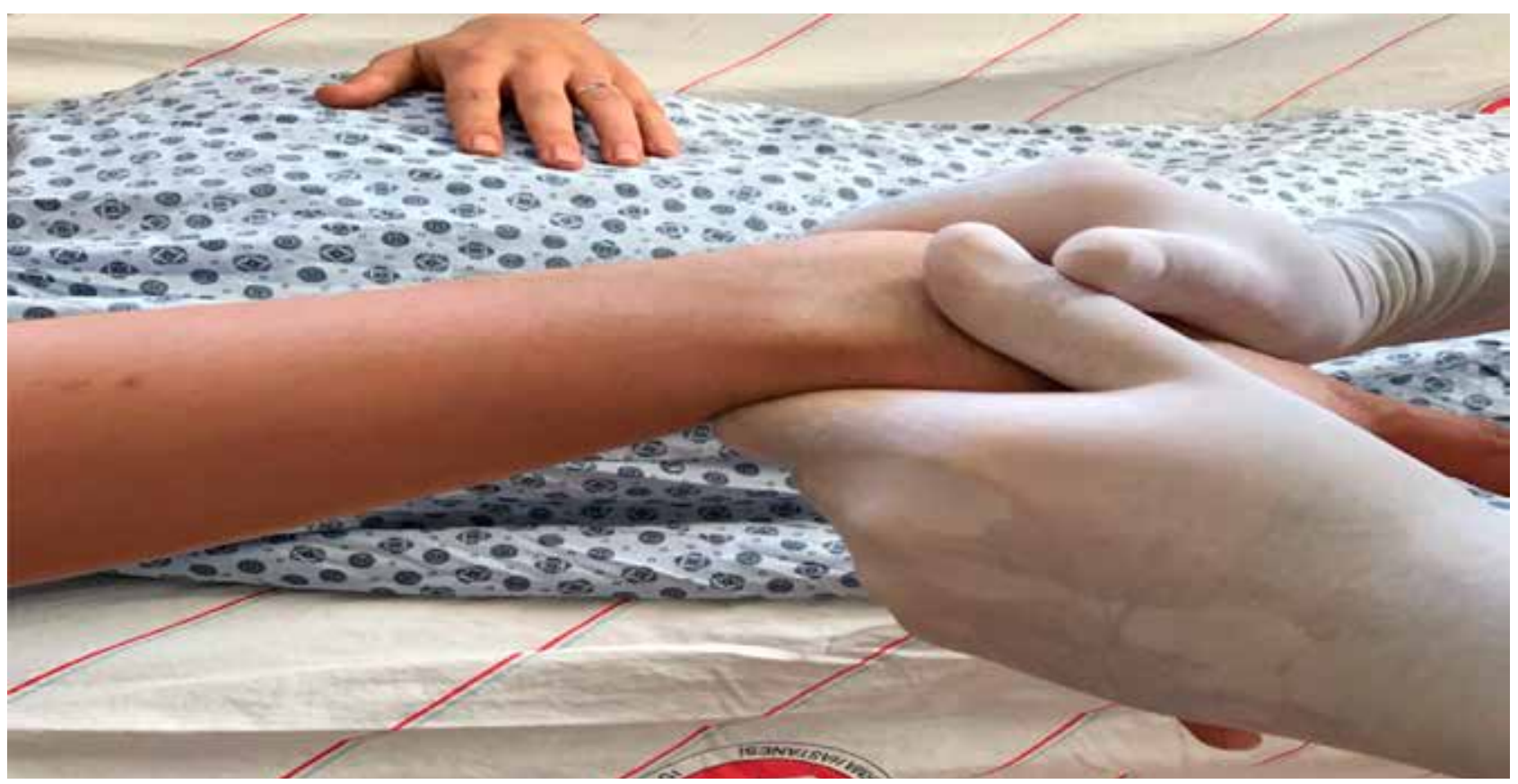

Şekil 1. Distal parçanın dorsale açılandığı radius distal uç kırı̆̆ı redüksiyon manevrası: doğrusal çekme sonrası distal parça fleksiyon ve ulnar deviyasyona getirilir.

önceki ve sonraki kemik boyunca, eklem dışı kırıklarda ise bir önceki ve bir sonraki eklemi sabitleyecek şekilde alçı yapmak gereklidir. Ancak, radius distal uç kırıklarında dirsek altı alçıların en az dirsek üstü olanlar kadar etkin olduğuna dair çalışmalar vardır. ${ }^{[1,2]}$

\section{Kapalı redüksiyon}

Kırığı yerine yerleştirmek için doğrusal çekme ve kırık oluşum mekanizmasının tersine kuvvet uygulanmalıdır. Bunun için, kırığın oluşumu ve yer değiştirmesine neden olan kuvvetler anlaşılmalıdır (Şekil 1).

\section{Alçılama tekniği}

Sirküler alçı uygulaması, alçılı sargı veya fiberglas malzemenin alçı çorabı veya pamuk sarılmış ekstremiteye çepeçevre sarılmasıyla yapılır. Alçı pamuğu, ekstremitenin distal kısmından proksimaline doğru, her döngüde öncekinin yarısını örtecek şekilde ve ekstremitenin her yerinde en az iki kat olacak şekilde sarılmalıdır. Alçı pamuğunun az kullanılması ciltte bası yaralarına neden olabileceği gibi, fazla kullanılması da kırıkta yeniden yer değiştirmeye zemin hazırlayabilir. Sıcak su ile alçıyı ıslatmak, alçının erken sertleşmesine ve sertleşirken daha yüksek sıcaklığa ulaşmasına neden olur. Yüksek sıcaklıktaki alçı, özellikle alçı pamuğu uygun bir şekilde sarılmadıysa, ciltte yanıklara neden olabilir. Daha soğuk su ile ıslatılan alçı ise daha uzun sürede sertleşir. Alçı iyice ıslatıldıktan sonra mümkün olduğunca ıslak şekilde sarılır; çok fazla suyu sıkılmamalıdır. Alçı sarılırken ekstremiteden ayırmadan sarılmalıdır; böylece alçı rulosu ile ekstremite arasında oluşan sıvı alçıdan kısım, katmanlar arasında hava kalmasını engeller. Alçı katmanları arasında hava bırakmamak alçının gücünü ve dayanıklılığını arttıracaktır. İyi yapılmış bir alçı 4-6 kat sarılmış olmalıdır.

\section{E. Şekillendirme (molding)}

Alçı sarılması sırasında alçıya el ile şekil verilir (Şekil 2). Her kat alçı mold edilmeli ve sonra diğer kat alçı sarılmaya başlanmalıdır. Arzu edilecek konumda olacak şekilde her iki el ile alçı sürekli sıvazlanarak şekillendirilir. Alçının deformiteye karşı yönde işlev görmesi, üç nokta prensibine dayanır. Bu yüzden, şekillendirme işlemi sırasında 'üç nokta ilkesi' göz önünde bulundurulmalıdır. ${ }^{[3,4]}$ Fazla sıkı sarmaktan ve cilde bası yapacak şekilde alçı üzerine parmak ucu ile baskı uygulamaktan kaçınılmalıdır. Şekillendirme el ve parmak ayası ile yumuşak bir şekilde yapılmalıdır. Alçı şekillendirilmesi, alçı şeklini koruyacak kadar kuruyunca tamamlanır.

\section{F. Alçılama yapılırken sık yapılan hatalar}

- Alçı pamuğunun uygun olmayan şekilde veya yetersiz sarılması; az sarılan pamuk bası yarası ve yanıklara, fazla sarılan pamuk kırıkta yer değiştirmeye neden olabilir. 


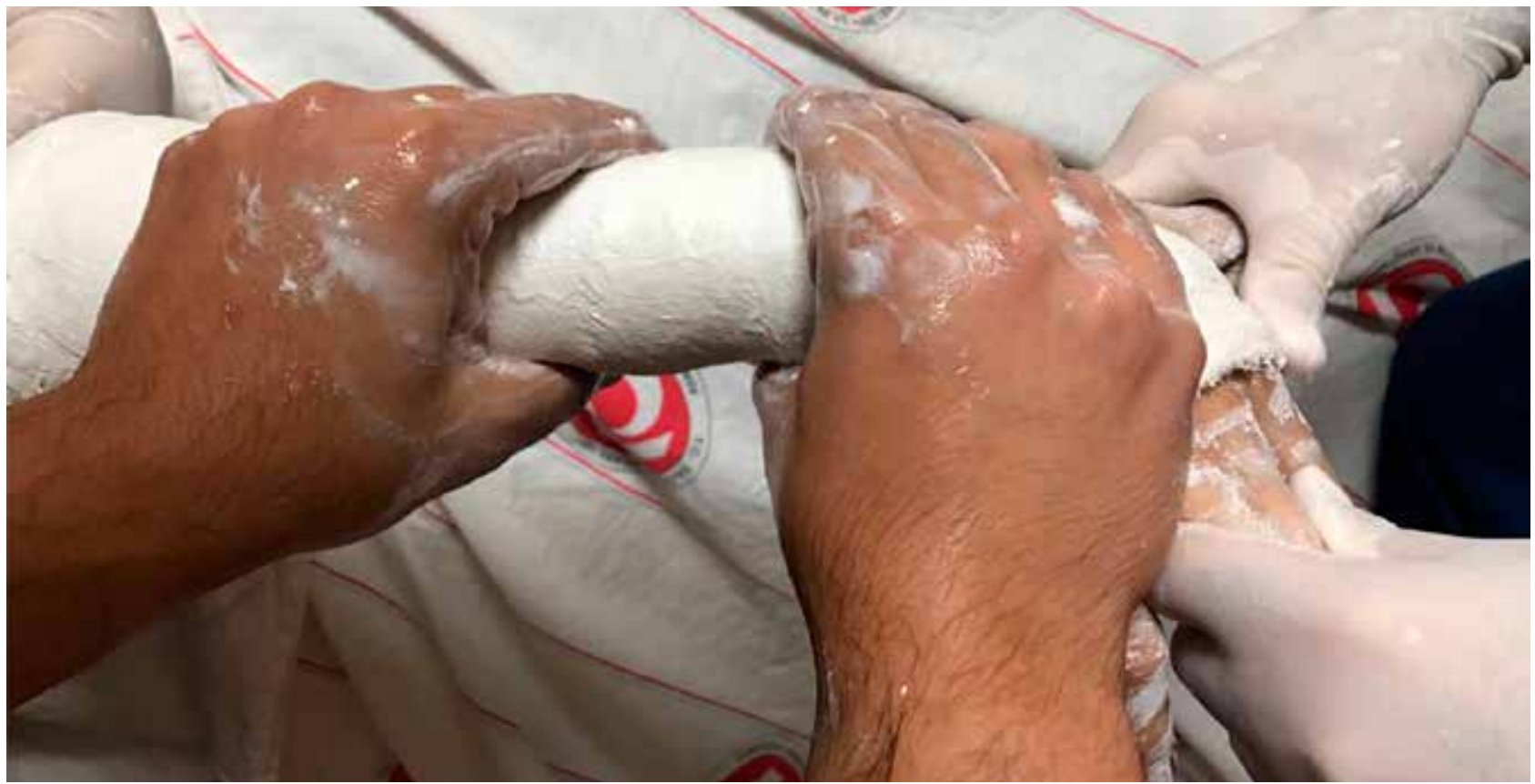

Şekil 2. Şekillendirme (mold).

- Alçıyı sıcak su ile ıslatmak; alçının donma süresini kısaltmak için sıcak suda ıslatmak tercih edilebilmektedir. Bu da alçının donarken daha fazla ısınmasına ve yanıklara neden olabilmektedir.

- Gereğinden daha kalın alçı yapmak; daha çok ısınma ve yanığa neden olabilir.

- Alçının tam donmasını sağlayamamak; alçının sertleşmesi tamamlanmadan şekil verme işleminin sonlandırılması, alçının şeklinde bozulmaya, cilt basısı ve yanıklara neden olabilir.

- Alçının katmanlaşması.

- Gereğinden uzun alçı yapılması, eklemlerin doğru konumda sabitlenmemesi.

\section{G. Alçı ve atel uygulaması komplikasyonları}

- Kompartman sendromu; alçı tedavisi sonrası görülebilecek en ciddi komplikasyondur. Yaralanmış ekstremitede kan akımını bozacak şekilde yumuşak doku basıncının yükselmesi ile kalıcı kas ve sinir harabiyeti oluşmasıdır. Alçı içerisindeki ekstremitenin pasif hareketi ile ağrı olması, kompartman sendromu açısından uyarıcı olmalıdır. Bunun yanında; ekstremitede uyuşukluk, iki nokta ayrımının yapılamaması, kapiller dolumun azalması, solukluk ve son aşamasında nabızların zayıflaması veya alınamaması görülebilir. Kompartman sendromu şüphesi olan bir alçı hemen açılmalıdır. Alçı altındaki çorap ve pamuk da mutlaka kesilmeli ve atel veya bivalf alçıya geçilmelidir. Şayet alçı çıkarılması sonrası şikayetler birkaç dakika içinde gerilemezse, kompartman basıncı ölçümü veya gerekiyorsa cerrahi fasyatomi uygulanmalıdır.

- Bası yaraları; çoğunlukla uygun yapılmamış alçı ile alakalıdır. Alçıya pansuman amacı ile pencere açıldığı durumlarda, pansuman sonrası kapak mutlaka uygun şekilde geri kapatılmalıdır. Yazarlar, kapatılmadığı durumlarda pencere ödemine bağlı basılar sonucu osteomiyelite kadar giden olgular saptamışlardır.

\section{- Alçı dermatiti;}

- Sinir yaralanması; yüzeysel sinirlerin bulunduğu vücut bölgelerinde bası olması ile ortaya çıkabilir. Özellikle uzun kol alçılama esnasında, ulnar sinir nöropraksisine dikkat etmek gerekir.

\section{RADIUS DISTAL UÇ KIRIKLARI}

Distal radius kırıkları genellikle açık el üzerine düşme ile oluşur. Metafiz bölümünde oluşan basit kırıklardan, eklem içine ulaşan parçalı, karmaşık ve zor kırıklara kadar olan geniş bir yelpaze gösterir. Tüm distal radius kırıklarının \%48'inin eklem dışı kırıklar olduğu, kalan eklem içi kırıklarının ise \%10'unun kısmen eklemi ilgilendirdiği, \%42'sinin ise tamamen eklem içi olduğu 
bildirilmiştir. ${ }^{[5]}$ Eklem dışı kırıkların içinde \%15'lik bir kısmın çok az kayma gösterdiği görülmüş ve bu kırıkların esas konservatif tedavi edilen hastalar olduğu sonucuna varılmıştır. Eklem dışı kırıkların çoğunluğunun, $\% 26$ oranla, konservatif tedaviye uygun olmayan dorsal metafizyel parçalanma gösteren kırıklar olduğu fark edilmiştir.

Literatürde tanımlanmış birçok sınıflandırma mevcuttur. Melone sınıflandırması, distal radiusu dört ana parçaya ayırarak değerlendirir: 1) cisim, 2) radyal stiloid, 3) dorsal mediyal parça ve 4) volar mediyal parça. Cerrahi tedaviyi tanımlayan ve endikasyonları belirleyen yaygın bir sınıflandırma olmasına rağmen, standart röntgen görüntülerine göre kullanılmasının doğruluğu ve güvenilirliği tartışmalıdır. ${ }^{[6,7]}$ AO/ASIF (Association for Osteosynthesis / Association for the Study of Internal Fixation) sınıflandırması; eklem dışı, kısmen eklemi ilgilendiren ve eklem içi olacak şekilde üç ana gruba ve 27 alt tipe ayrılır; yüksek güvenilirliği olan bir sınıflandırmadır. ${ }^{[6,7]}$ Fernandez, kırığın oluş mekanizmasına göre bir sınıflandırma tanımlamıştır. Bu sınıflandırmanın, pratik olması ve tedaviyi yönlendirmesi gibi avantajları vardır; stabil olup olmama, beraberinde başka yaralanmaların varlığı, pediatrik karşılıkları gibi değişkenler değerlendirilebilmektedir. ${ }^{[6,7]}$

Distal radius kırı̆̆ı tedavisinin amaçları, hastaya ağrısız yeterli bir el bileği hareketi kazandırmak, erken ve uzun vadede dejeneratif değişiklik riskini azaltmaktır. Son yıllarda gelişen ve çok iyi sonuçlar alınan cerrahi tedavi seçenekleri olmasına rağmen, bazı kırıklar için kapalı redüksiyon ve alçı ile tespit seçeneği halen altın standart tedavi yöntemidir.

Konservatif tedavi, kendine göre zorlukları olan zahmetli bir yöntemdir. Sık radyolojik ve klinik takip gerektirir. Redüksiyonun takibi ve redüksiyon kaymalarının önlenmesi için sık alçı değişimleri gerekebilir. Bununla beraber, hangi kırı̆ga konservatif tedavinin uygulanacağı kararını verirken göz önünde bulundurulması gereken esas ölçüt, kapalı redüksiyon sonrası kırığın redükte olabilmesi ve stabil kalabilmesidir.

Bu tedavinin amacı, kırığın anatomik düzgünlügüünün sağlanması ve kemik iyileşmesinin olgunlaşacağı 4.-6. hafta sonuna kadar bu düzgünlüğün alçı içinde korunmasıdır. Alçı içinde kırığın redüksiyonunun devamı ancak, alçının temas etkisi, yumuşak dokuların gerginliği ve yumuşak doku kılıfının hidrolik basıncı sayesinde olabilir. Stabil kırıklar denildiğinde, kaymamış veya kaymış ama redüksiyon manevraları ile düzeltilip pozisyonu alçı içinde korunabilen kırıklar ile, $5^{\circ}$ 'den az dorsal açılanma ve 2 mm'den az kısalma gösteren eklem dışı kırıklar anlaşılır. Başlangıç grafisinde parçalanma ve aşırı açılanma gösteren veya eklem içine uzanan kırıklar, ulnada eşlik eden kırıklar veya ileri derece osteoporozu olan kırıklar, stabil olmayan kırıklardır ve bu, alçı içinde ikincil kayma ihtimali yüksek kırıklar anlamına gelir. ${ }^{[5,8-10]}$

Konservatif tedavinin endikasyonları;

1. Sağlam tarafla karşılaştırıldığında distal radioulnar eklemde (DRUE) $<5 \mathrm{~mm}$ radyal kısalık

2. Anteroposterior grafilerde $>15^{\circ}$ radyal inklinasyon

3. Lateral grafide $0-20^{\circ}$ arasında volar tilt

4. <2 mm eklem içi basamaklanması olan kırıklar alçı ile tedavi edilebilir. Bu kırıkların konservatif tedavi sonuçları ve uzun dönem prognozları çok iyidir. Alçı ya da özel yapım ateller kullanılabilir. ${ }^{[5]}$

Eklem içi ve diğer stabil olmayan kırıklarda konservatif tedavi uygulanması tercih edilmez. ${ }^{[5,9,11]}$ ileriye dönük randomize 90 hastanın değerlendirildiği bir çalışmada, eklem içi kırıklarda uygulanan konservatif tedavinin başarı şansının sadece $\% 43$ olarak tespit edildiği bildirilmiştir. ${ }^{[12]}$ Kabul edilebilir kapalı redüksiyon kriterleri ile beraber instabilite bulguları olan kırıklarda cerrahi tedavi endikasyonu vardır. Yirmi dereceden fazla dorsal açılanma, dorsal kortekste parçalanma, 60 yaş üstü hastalar, beraberinde ulna kırığı varlığı, makaslama kırığı, çıkıkla beraber olan kırıklar, 2 mm'den fazla eklem içi basamaklanma ve $5 \mathrm{~mm}$ 'den fazla kısalık, instabilite kriterleri olarak tanımlanır. ${ }^{[13]}$ İnstabil kırıklarda cerrahi tedaviye gereksinim duyulur.

Kapalı redüksiyon ve alçılama tekniği ile, cerrahinin potansiyel komplikasyonlarından korunarak iyi sonuçlar elde etmek mümkündür. Bununla birlikte, kırık çökmesi (kollaps) ve yanlış kaynama (malunion) riski her zaman vardır. Konservatif tedavinin temelini kısa kol veya uzun kol alçılama oluşturur. ${ }^{[1]}$ Ancak, uzun kol alçı yapılıyorsa dirsek pozisyonu baştan itibaren $90^{\circ}$ olmalı ve değişmemelidir. El bileğinin pozisyonu $10-15^{\circ}$ ulnar deviyasyon ve $10-20^{\circ}$ fleksiyon olmalıdır (Şekil 3). ${ }^{[8]}$ Aşırı fleksiyondan $\left(>20^{\circ}\right)$ kaçınılmalıdır. Bu pozisyonda dorsal kompartmandaki tendon ve bağların ligamentotaksis etkisi redüksiyonun devamında önemli rol oynar. El bileğinin aşırı palmar fleksiyonu karpal tünel sendromuna neden olacağından, aşırı fleksiyondan kaçınılmalıdır. Alçı, distal avuç içi çizgisinin distaline geçmemeli, metakarpofalangeal (MF) eklemin tam fleksiyonuna izin verecek şekilde olmalıdır. illk üç hafta hastanın sık takip edilmesi, bollaşmanın erken fark edilmesi ve kırık redüksiyonu bozulmadan önce alçının değiştirilmesi çok önemlidir. ${ }^{[5,10]}$ 


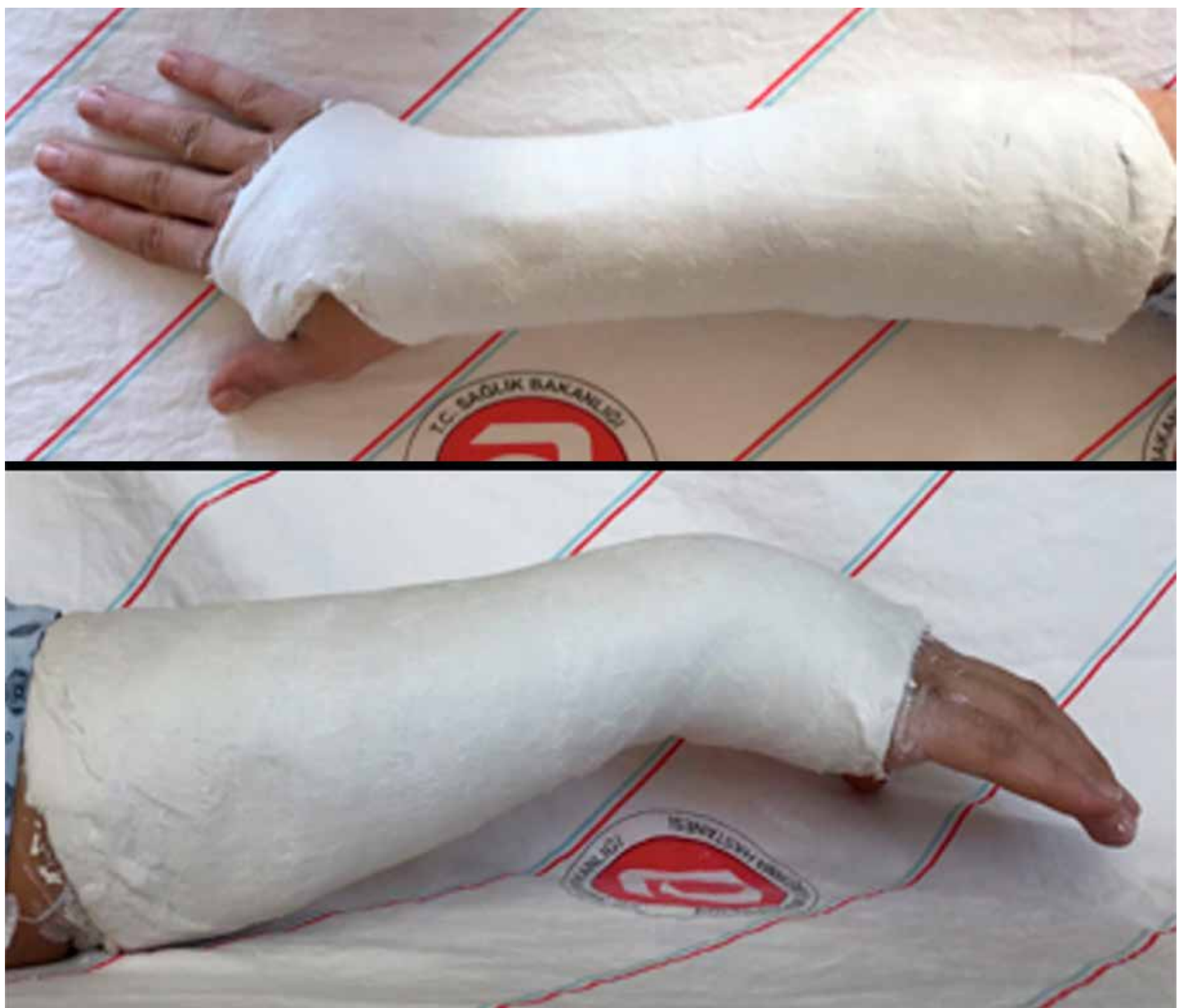

Şekil 3. Radius distal uç kırıklarında alçılama.

Lokal, bölgesel veya genel anestezi ile önce uygun ağrı kontrolü yapılır. Lokal hematom bloğu, ciddi şsşliği olmayan düşük enerjili kırıklarda tercih edilir. Zor redükte edilecek kırıklarda, geç redüksiyonlarda, kaymış kırıkların yeni redüksiyon manevralarında ve ödem, kontüzyon, açık yara gibi lokal yumuşak doku sorunu olanlarda, aksiller blok anestezisi gibi bölgesel anestezi tercih edilir.

Alçılama ve redüksiyon için iki temel yaklaşım söz konusudur. ${ }^{[5]}$

1. Direkt kırık fragmanın manipülasyonu.

2. Longitudinal traksiyonla indirekt kırık redüksiyonu.
Redüksiyon teknikleri, parmak halkaları ile distraksiyonu takiben deformiteyi; kırığın açılanmasını arttırarak direkt manipülasyonunu içermektedir. Elle direkt yerleştirme manevralarında, teorik olarak dorsale kaymış eklem dışı kırıklarda, sıklıkla "Sir Robert Jones'un tekniği" kullanılır. Bu teknikte önkol pronasyondadır. Eğer kırık volare kaymış ise, manevra önkol supinasyonda iken yapılır. Traksiyon kulelerinde uygulanan teknik ise skopi kontrolünde traksiyon altında yapılır. ${ }^{[5,14]} \mathrm{Bu}$ iki tekniğin karşılaştırıldığı ileriye dönük, kontrollü, randomize bir çalışmada, ilk hafta ve beşinci hafta sonunda radyolojik olarak istatistiksel anlamlı bir fark olmadığı bulunmuştur. 


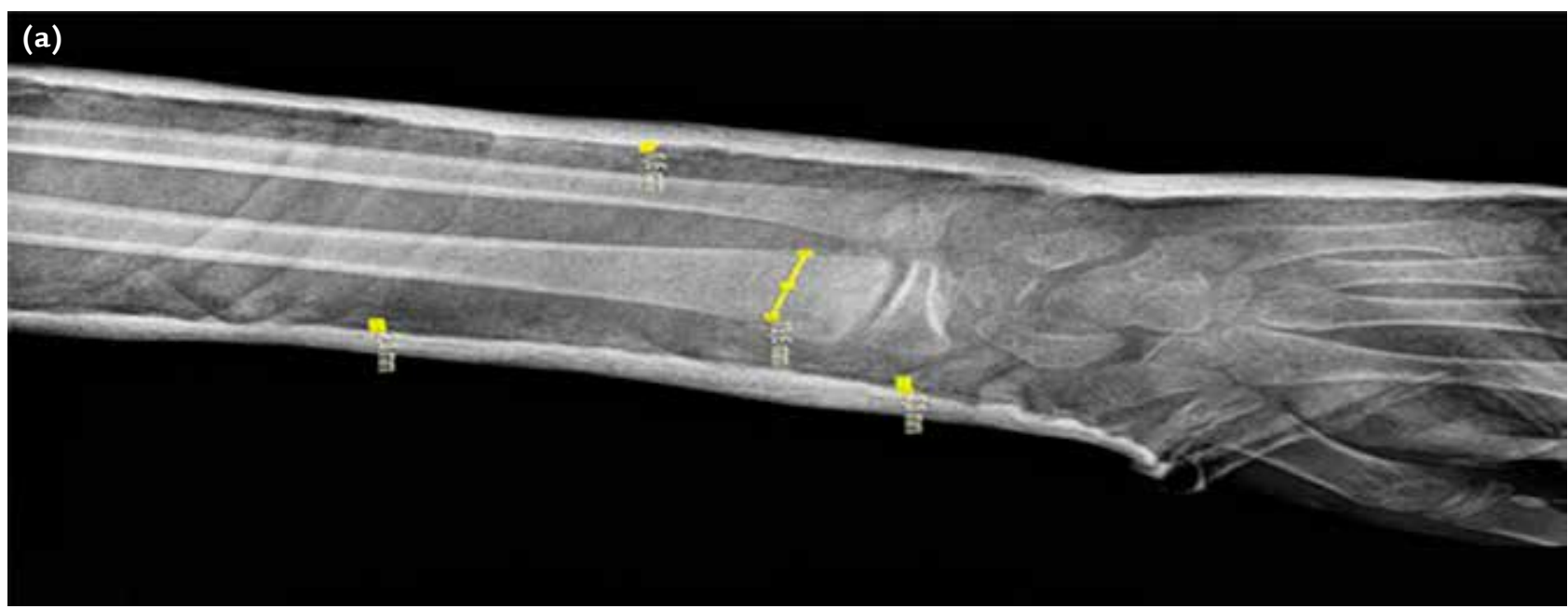

(b)

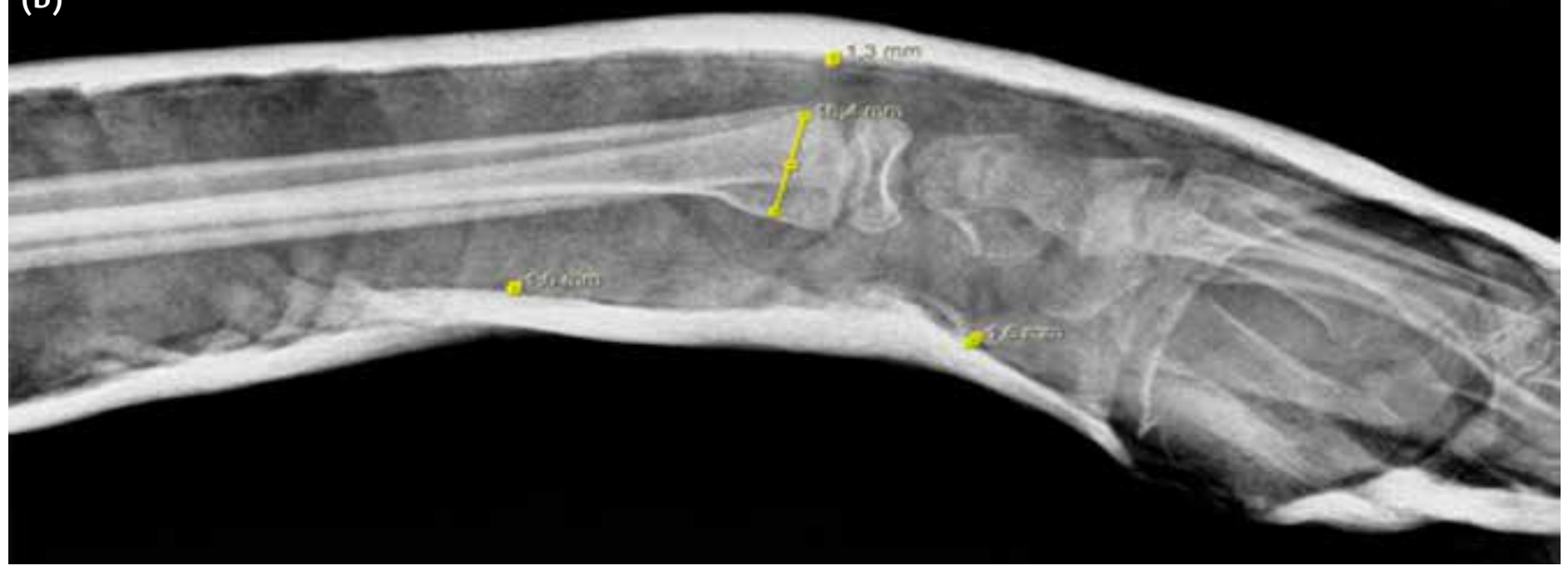

Şekil 4. a, b. Üç nokta prensibi: Anteroposterior grafide ‘üç nokta prensibi' (a). Lateral grafide 'üç nokta prensibi’ (b).

Alçının bol olup olmadığını direkt grafilerden tespit edebilmek için kullanılan indeksler mevcuttur:

1. Cast index (alçı indeksi) ${ }^{[15]}$

2. Padding index (pamuklama indeksi) ${ }^{[16]}$

3. Gap index (boşluk indeksi) ${ }^{[13]}$

4. Three-point index (üç nokta indeksi) ${ }^{[17]}$

Alemdaroğlu ve ark., yaptıkları çalışmada üç nokta indeksinin duyarlılığını \%94, özgüllüğünü \%95 olarak göstermiştir. ${ }^{[17]}$ Diğer indekslere göre duyarlılık ve özgüllügüu daha yüksektir. Alçılama sonrası redüksiyon stabilitesini anlamak için öncelikle AP ve yan grafilerde kırığı manipüle edebilecek üç nokta bulunmalıdır. Bu noktalar; kırık bölgesi, distal (metafiz) ve proksimal (cisim) alçı ve cilt arasındaki en dar boşluklardır. Bu noktalarda alçı ile cilt arasındaki mesafeler tespit edilir. Kırığın horizontal ve sagittal düzlemlerde redükte kısmı değerlendirilir. Bu alanda kırık temas yüzeyleri arasındaki mesafe tespit edilir. Boşlukların kırık temas uzunluklarına oranı 'three point index' değerimizi verir (Şekil 4). Yapılan redüksiyon ve alçılama sonrası "üç nokta indeksi" değerleri 0,8'den yüksekse, kayma riski de yüksektir. Eğer değerimiz $>0,8$ olarak tespit edilirse; alçımızın gevşek olduğunu, yüksek ihtimal ile redüksiyon kaybı yaşayacağımızı gösterir. Eğer değerimiz $<0,2$ olarak tespit edilirse; alçımızın sıkı olduğunu gösterir.

Üç nokta prensibiyle alçı yapmak önemlidir. Bu sayede dorsal açılanma ve radyal deviyasyona karşı koyacak şekilde bir alçılama yapılması önerilir. Hang ve ark., diğer tüm klinik ve radyolojik risk faktörlerine göre üç nokta indeksini daha anlamlı bulmuştur. ${ }^{[18]}$ Devalia ve ark., alçılama tekniğini değerlendirmek için üç nokta 
indeksinin kullanılmasını önermişlerdir. Ayrıca, indeksin yeni başlayan asistanlar için herhangi bir redüksiyonun kabul edilebilirliğini anlama açısından öğretici olduğunu belirtmişlerdir. ${ }^{[19]}$ Marcheix ve ark., yaptıkları değerlendirmede; üç nokta indeksine göre alçı şekillendirilmesinin yetersiz olmasının tek önemli risk faktörü olduğunu belirtmişlerdir. Üç nokta indeksinin tekrar yer değiştirmeyi tahmin etme açısından mükemmel bir indeks olduğu yorumunu yapmışlardır. ${ }^{[20]}$ Yazarlar, üç nokta indeksinin redüksiyon kaybını tahmin etmedeki başarısını, alçılamanın en eski prensibi olan üç nokta tespit prensibine dayanmasına bağlamaktadırlar. ${ }^{[3]}$

Kısa kol ve uzun kol alçılama konusunda fikir birlikteliği yoktur. ${ }^{[15,21]}$ Alçı içindeki el bileği pozisyonu, alçının proksimal ve distal sınırları ve tespit süresi konularının tam olarak belirlenmesi gerekir. Dorsale açılanması olan, dorsal metafizde parçalanması olan kırıklarda el bileği $15^{\circ}$ fleksiyon, $10-15^{\circ}$ ulnar deviyasyon ve $25^{\circ}$ pronasyon pozisyonunda tespit edilir. Dikkat edilmesi gereken nokta; aşırı derecede fleksiyon ve ulnar deviyasyon pozisyonunun (Cotton-Loder pozisyonu) radyolojik olarak redüksiyonu korumasında belirli avantajları olmasına karşın, karpal tünel içinde aşırı basınç artmasına neden olarak, median sinirin etkilenmesi ve parmakların hareketinin zorlaşması gibi ciddi dezavantajları vardır. ${ }^{[5,10]}$ Alçı, distal avuç içi çizgisinin distaline geçmemeli, MF eklemin tam fleksiyonuna izin verecek şekilde olmalıdır.

\section{ÖNKOL KIRIKLARI}

Önkol kırıklarının tedavileri, ulna ve radiusun birbirlerine olan pozisyonel durumlarının el fonksiyonlarına olan direkt etkileri nedeniyle, diğer diyafiz kırıklarıyla karşılaştıııldığında daha fazla önem arz eder. Mükemmel olmayan tedaviler, hareket kaybı ve zayıf el fonksiyonlarına neden olabilir. ${ }^{[22]}$ Özellikle pronasyon ve supinasyonda radiusun ulna üzerinde olan hareketi, kemiklerin anatomik dizilimindeki açılarla direkt ilgilidir. Bu açılardaki sapmalar, özellikle pronasyon ve supinasyon kaybına neden olur. ${ }^{[23,24]}$ Bu kayıp elin fonksiyonlarını etkilediği için, radius ve ulna cisim kırıkları eklem içi kırıklar olarak kabul edilmektedir. ${ }^{[25]}$

Direkt travmalar başta olmak üzere önkol kırıkları birçok hasar mekanizması ile meydana gelebilir. Sıklıkla trafik kazaları gibi yüksek enerjili travmalar, yumuşak doku hasarlanması ve açık kırıklarla birliktelik gösterir. Önkol kırıkları sınıflandırıııken; kırık lokalizasyonu, kırık paterni, deplasman açısı ve miktarı, radiyoulnar eklemlerle ilişkisi, kemik kaybı ve yumuşak dokunun hasar durumu göz önüne alınır.
Önkol kırıklarında sıklıkla kullanılan sınıflandırma Ortopedik Travma Derneği tarafından da benimsenen, $A O$ grubunun yaptığı sınıflandırmadır. ${ }^{[26]} \mathrm{A}$ kırıklar ulna, radius ya da her iki kemiğin basit kırıklarını içerir. A1 ulnanın izole, A2 radiusun izole kırığını tanımlar. Her iki grupta da ".1", oblik kırıklar, “.2" transvers kırıklar ve ".3" kırıklı çıkıklar için kullanılır. (örn; A1.3 Monteggia kırığını, A2.3 Galeazzi kırı̆̆ını tanımlar) Tip B kırıklar kelebek fragman içeren kırıklardır. Aynı şekilde; B1 ulna, B2 radius, B3 her iki kemiği içeren kırıklar için kullanılır. Yine, “.1" intakt fragmanı, “.2" parçalı fragmanı ve ".3" kırıklı çıkığı tanımlar. Tip C kırıklar kompleks kırıklardır. C1 ulna için, C2 radius için, C3 her iki kemiği içeren kırıklar için kullanılır. C1.1 izole segmente ulna kırığı, C1.2 eşlik eden radius kırı̆̆ını, C1.3 parçalı ulna kırı̆̆ını tanımlar. C2.1 izole segmente radius kırığını, C2.2 eşlik eden ulna kırığını, C2.3 parçalı radius kırı̆̆ını tanımlar. C3.1 de her iki kemikte segmente kırık varlığını belirtir. C3.2, kemiklerden birinde segmente kırık varken diğerinin parçalı kırık içerdiğini, C3.3 her iki kemiğin düzensiz parçalı olduğunu belirtir.

Önkol kırıklarının tedavisi, konservatif ve cerrahi olmak üzere ikiye ayrılır. Tedavinin amacı; aksiyel dizilimi ve uzunluğu sağlamak, açılanmaları önleyerek kırığın kaynamasını beklemektir. Yapılan bir çalışmada, önkolun bir veya iki kemiğinde $10^{\circ}$ 'lik açılanmanın eklem hareket genişliğinde $20^{\circ}$ lik pronasyon ve supinasyon kaybına neden olduğunu, $20^{\circ}$ 'nin üzerindeki açılanmalarda ise radyoulnar interosseöz memrandaki aşırı gerilme nedeniyle ileri derecelerde hareket kısıtlılığı olabileceği belirtilmiştir. ${ }^{[27]}$ Başka bir çalışmada, rotasyonel kısıtlıı̆̆ın dizilim bozukluğunun olduğu bölgeye bağlı olduğu söylenmiştir. Orta 1/3'teki dizilim bozukluğunda, distal 1/3 kesime göre supinasyon kaybının pronasyon kaybından fazla olduğu belirtilmiştir. ${ }^{[28]}$

Erişkinlerde radiusun $10^{\circ}$ 'den fazla açılanması veya her iki radyoulnar eklemden birinde subluksasyon veya luksasyon, ulnanın kırıklarında $10^{\circ}$ 'den fazla açılanma olması cerrahi tedaviyi gerektirir. Çocukluk çağı önkol kırıklarının yaklaşımı erişkinlere göre farklılık göstermektedir. Yapılan çalışmalar, $10^{\circ}$ üzerindeki açısal şekil bozukluklarının ve $30^{\circ}$ 'den fazla olan rotasyonel bozuklukların önkolun rotasyon hareketlerini anlamlı bir şekilde kısıtladığını göstermiştir. ${ }^{[29]}$ Bu unsurlar göz önünde tutulduğunda, 10 yaşından küçük çocuklarda $15^{\circ}$ 'lik açılanma ve $45^{\circ}$ 'ye kadar olan rotasyon uygunsuzluğu, 10 yaşından büyük çocuklar için ise $10^{\circ}$ 'lik açılanma ve $30^{\circ}$ 'lik rotasyon uygunsuzluğu kabul edilebilir redüksiyon kaybı sınırlarıdır. Belirtilen açılanmalar yoksa kırık uçlarının üst üste binmesi ve önkol kısalığının konservatif tedavi sonucunu olumsuz olarak etkilemeyeceği kabul edilmektedir. 


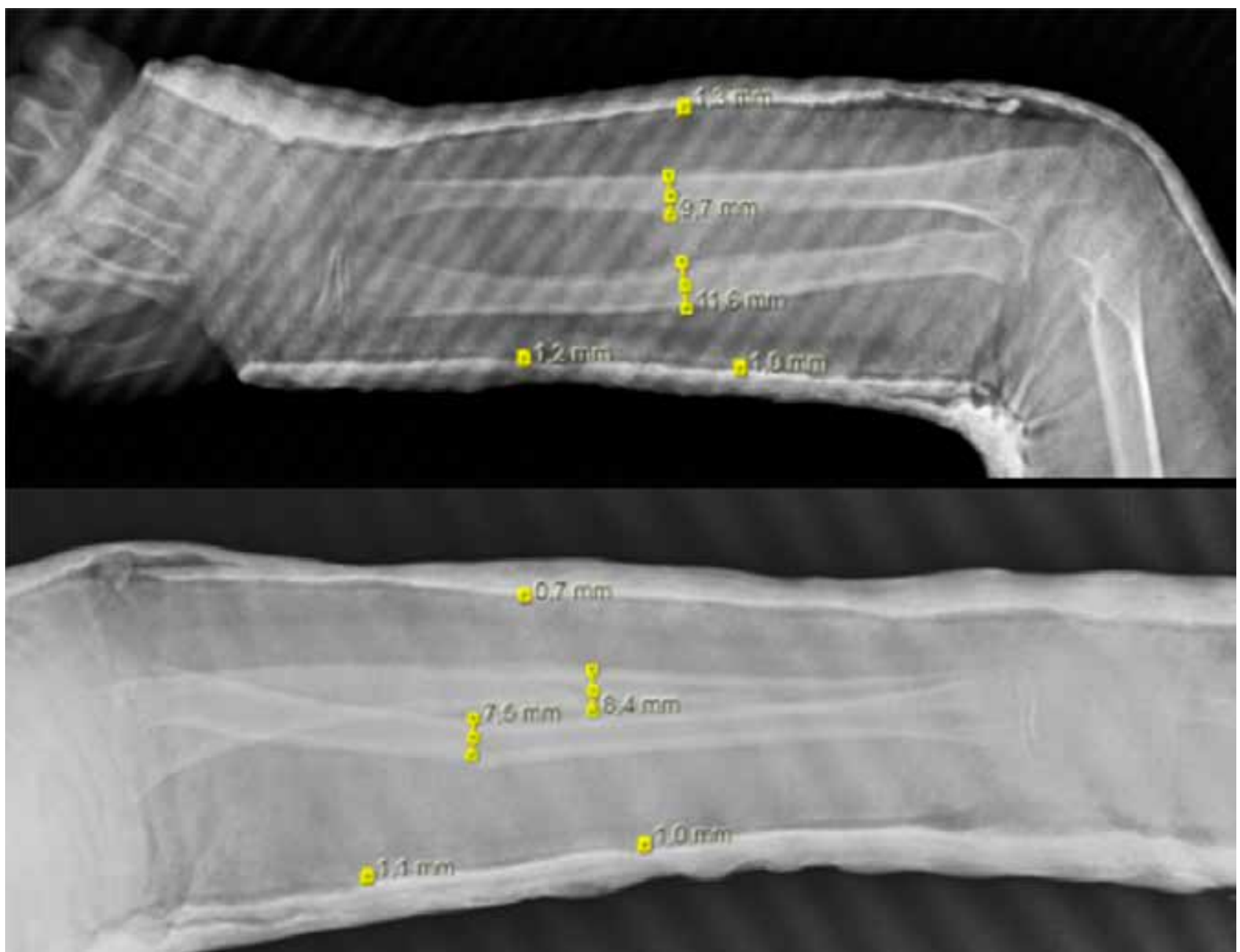

Şekil 5. Önkol kırıklarında 'üç nokta prensibi' .

Kırık redüksiyonu kadar, alçılama sonrası redüksiyon stabilitesini de anlamak için üç nokta prensibiyle alçı yapmak önemlidir. Dorsale yer değiştirmiş bir kırı̆̆ın redüksiyonundan sonra; distal ve proksimal parçaya dorsal ve kırık hattında ise volar baskılar oluşur. ${ }^{[4]}$ illtar ve ark. ${ }^{[4]}$, Alemdaroğlu ve ark.'nın ${ }^{[3]}$ radius distal uç kırıklarında tanımladığı üç nokta prensibini önkol kırıklarında uygulamışlar ve \%84 duyarlılık \%97 özgüllük tespit etmişlerdir. Bu değerler, diğer indekslere göre daha başarılı bir indeks olduğunu göstermektedir. ${ }^{[4]}$ 'Üç nokta prensibi' uygulanırken, öncelikle kırık redüksiyon manipülasyon noktaları belirlenir. Bu noktalar; kırık bölgesi, distal (metafiz) ve proksimal (cisim) alçı ve cilt arasındaki en dar boşluklardır. Bu noktalarda alçı ile cilt arasındaki mesafeler tespit edilir. Kırığın horizontal ve sagittal düzlemlerde redükte kısmı değerlendirilir. Bu alanda kırık temas yüzeyleri arasındaki mesafe tespit edilir. Boşlukların kırık temas uzunluklarına oranı 'three point index' değerimizi verir. Yapılan redüksiyon ve alçılama sonrası "üç nokta indeksi" değerleri 0,8'den yüksekse kayma riski yüksektir (Şekil 5).

Önkol kırıklarında 'üç nokta prensibi' uygulanırken bir diğer dikkat edilmesi gereken husus; kırık hattının kas insersiyo ve origolarına olan konumudur. Biseps ve supinatör kasları, insersiyolarından dolayı kırık üzerinde rotasyonel kuvvetler oluşturur. Pronator teres şaftın ortasına, pronator kuadratus da distal radiusun $1 / 4$ distal kısmına yapıştıklarından, rotasyonel ve açılandırıcı kuvvetler meydana getirir. Redüksiyon manevrası sırasında bu kuvvetleri dikkate almalıyız. Redüksiyon sonrası eğer kırık hattı önkol proksimal 1/3'lük alanda ise supinasyonda, orta $1 / 3^{\prime}$ lük alanda ise nötral pozisyonda, distal $1 / 3$ 'lük alanda ise pronasyonda alçılama yapılarak stabilizasyon sağlanmalıdır. 


\section{SKAFOID KIRIKLARI}

Skafoid kırıkları, sıklıkla dışa açılmış el üzerine düşme ya da el bileğinin dorsifleksiyona zorlandığı yaralanmalar neticesi görülür. ${ }^{[30-32]}$ Skafoid kırıkları en sık genç yaş grubu ve erkeklerde görülürr. ${ }^{[33]}$ Tassel, epidemiyolojik çalışmasında, insidansı yılda \%o1,21; yaş grubunu ise 20-24 yaş olarak bildirmiştir. ${ }^{[34]}$ Skafoidin karpal kemikler içinde kırılma sıklığı \%70'tir. ${ }^{[32]}$ En sık kırılan karpal kemiktir. Skafoid, anatomik olarak; proksimal kutup, bel ve distal kutup (tüberkül) olarak ayrılır.

Skafoidin kan akımı desteği çok narindir; kırık olduğunda, bu akım kesintiye uğrayarak iyileşmeyi engelleyebilir. ${ }^{[33-36]}$ Skafoid kırıklarının \%13-50'sinde avasküler nekroz görülebilir. ${ }^{[33-37]}$ Skafoidin arteriyel beslenmesinin \%70-80'i, radyal arterden gelen ve dorsalden kemiğe giren damardan sağlanır. Kalan \%20-30'luk kısım volarden, direkt radyal arterden ya da yüzeyel palmar arter dalından kaynaklanıp skafoidin distal palmar bölgesine ulaşan dallardan beslenir. Proksimal kutbun beslenmesi, direkt olarak kemik içi kan dolaşımından retrograd yolla oluşur. ${ }^{[38,39]}$

Skafoid kırıklarının \%70'i bel, \%10-20'si distal kutup, \%5'i tüberkül ve \%5'i proksimal kutupta meydana gelir. Skafoid kırıkları; stabilite, kırık yerleşimi, kırık planı ve osteonekrozun varlığına göre sınıflandırılmıştır.

Otto Russe, skafoid kırıklarını şekline göre, horizontal oblik, transvers ve vertikal oblik olarak üçe ayırmış ve oblik kırıkların stabil olmadıklarını 1960 yılında vurgulamıştır. ${ }^{[30]}$ Herbert ve Fisher, 1984 yılında skafoid kırıklarının cerrahi tedavisinde kullanılmak üzere geliştirdikleri kompresyon vidasını tanımlarken, aynı zamanda röntgen görüntülerine dayanarak da bir sınıflama tanımlamışlardır. ${ }^{[31]}$

Skafoid kırıklarında cerrahi tedavi endikasyonları şunlardır[ ${ }^{40-42]}$ :

1. Kırık hattında $1 \mathrm{~mm}$ 'den fazla yer değiştirme (kaynamama oranı yaklaşık \%50)

2. Proksimal kutup (yer değiştirmiş veya değiştirmemiş kırık)

3. Büyük kemer yaralanması (transskafoid perilunat yaralanma)

4. Parçalı kırık

5. Meslek (cerrah, elit sporcu)

Erken teşhis sonrası konservatif ve cerrahi tedavi ile, \%90'ın üzerinde kaynama oranı elde edilmektedir. Akut olarak saptanıp tedavi edilen skafoid kırıklarının çoğunluğunda, yaklaşık üç ayda iyileşme meydana gelir. ${ }^{[43]}$

\section{Proksimal Kutup Kırıkları}

Kayma olup olmadığına bakılmaksızın, stabil olmayan kırıklar sınıfına girer ${ }^{[4,45]}$ ve alçı tespiti ile tedavi süresi 12 hafta ya da daha uzun olabilir. Proksimal kutup kırıklarında, başlangıçta dizilim düzgün olsa da, erken tanı ve uygun tedaviye rağmen konservatif tedavi ile kaynama oranı \%66'dır. Bu tip kırıklar cerrahi olarak tedavi edilmelidir. ${ }^{[44,45]}$

\section{Skafoid Bel Kırıkları}

Konservatif tedavi kararı alınmış skafoid fraktürlerinde çeşitli alçılama metodları mevcuttur. Akut kayma olmamış skafoid bel kırıklarında, stabilitenin devamı için uygulanan dirsek üstü başparmağı içine alan

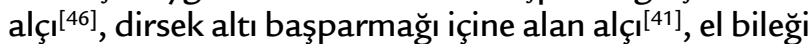
nötral veya hafif ekstansiyonda tespit ${ }^{[47]}$, el bilek ekstansiyon alçılı tespiti[ ${ }^{[42]}$ ile kaynama oranı \%90-100 arasındadır. ${ }^{[41-43]}$

\section{Dirsek Üstü Alçı}

Daha önceki çalışmalar dirsek üstü alçılama ile skafoid fraktürlerinin kaynamasının \%95 olduğunu belirtse de, güncel çalışmalar dirsek üstü alçılamanın avantajı olmadığını göstermiştir. ${ }^{[48]}$

\section{Skafoid Alçısı}

1942'de Böhler ${ }^{49]}$ tanımlamıştır. Günümüzde Trojan ve ark.'ları yaptıkları çalışmada, bu alçılamanın sadece yüksek derece stabil olmayan ve proksimal uç kırıklarında kullanılması gerektiğini belirtmişlerdir. ${ }^{[50]}$ Clay ve ark. yaptıkları çalışmada, başparmağın tespit edilip edilmemesinin kaynama oranında değişiklik yapmadığını göstermişlerdir. ${ }^{[51]}$ Skafoid kırıklarında, başparmağı içine alan veya almayan alçılama tercihleri arasında tam bir fikir birlikteliği yoktur. Ancak genel yaklaşım, başparmağı içine alacak şekilde yapılan, $10^{\circ}$ fleksiyon ve radyal deviasyon uygulanan alçılamalardır (Şekil 6). Konservatif tedavi kararı verilen skafoid kırıklarında, kırık bölgesine göre alçı takip süreleri belirlenmiştir. Tedavi süreleri, distal $1 / 3$ 'lük alandaki skafoid kırıklarında ortalama $6-8$ hafta, orta $1 / 3^{\prime}$ 'ük alanda $8-12$ hafta, proksimal 1/3'lük alandaki bir skafoid kırığında ise $12-14$ haftaya kadar uzayabilir. ${ }^{[48]}$

Alçı tespiti, kayma olmayan kırıklar için 6-8 hafta uygulanır ve kaynama bilgisayarlı tomografi (BT) ile değerlendirilir. BT'de kaynama yok ise alçı tespitine 4-6 hafta daha devam edilir. Direkt grafi veya BT ile takiplerde kaynama olmayan olgularda, kırık hattında ortaya çıkacak aralık veya açılanmada ya da 12 hafta sonunda kaynamayan kırıklarda, cerrahi tedavi seçenekleri düşünülmelidir. 


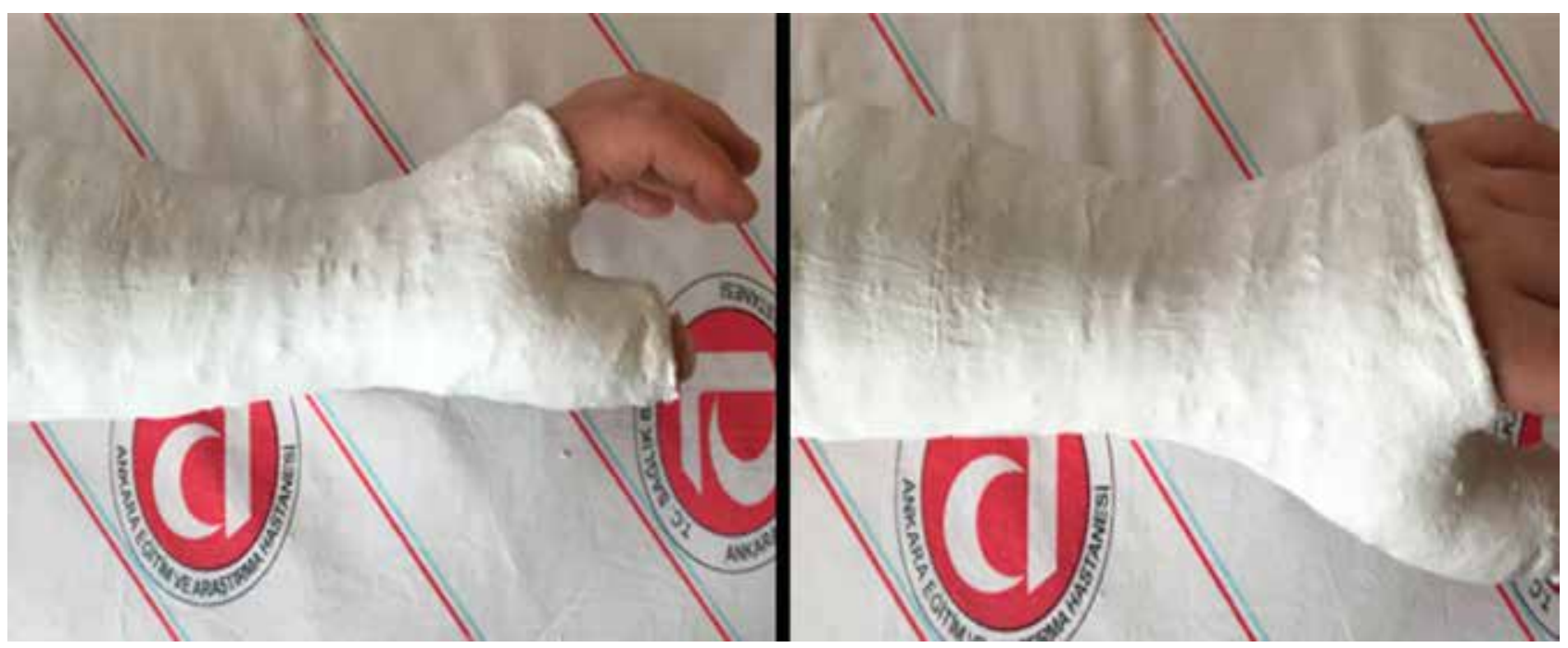

Şekil 6. Skafoid alçısı.

\section{BOKSÖR KIRIKLARI}

Metakarp ve falanks kırıkları, tüm kırıkların yaklaşık \%10'unu teşkil eder; metakarp kırıkları ise tüm el kırıklarının \%30-40'nı oluşturur. En sık görülen, 5. metakarp boyun kırı̆̆ıdır (\%10). Beşinci metakarp boyun kırı̆gı, özelliği olan ve sık görülen bir kırık tipidir. Boksör kırı̆ğ olarak da adlandırılır. Beşinci metakarp boynu palmara doğru yer değiştirir. Direkt veya indirekt mekanizmalarla ortaya çıkabilir. Oluşan kırığın tipi, travma esnasında uygulanan kurvetin özelliğine ve yönüne göre değişebilmektedir. ${ }^{[52]}$ Aksiyel yüklenmelerde, kırıklar eklem içi uzanım gösterebilir. ${ }^{[53,54]}$ Metakarp kırıkları, intrensek kasların çekmesi nedeniyle çoğunlukla dorsale doğru açılanır..$^{[5]}$

Metakarp kırıklarının radyolojik muayenesinde, üç yönlü el grafisi (postero-anterior (PA), lateral ve oblik) tanı koymak için çoğu kez yeterlidir. Yapılan bir çalışmada, spor yaralanmaları sonrası görülen metakarp kırıklarının \%80 oranında stabil olduğu ve konservatif yöntemlerle tedavi edilebildiği bildirilmiştir. ${ }^{[54]}$

Kapalı olarak düzeltilemeyen veya düzgün hali korunamayan kırıklar, çoklu metakarp kırıkları, eklem içi kırıklar, kabul edilen değerlerin üzerinde açılanma gösteren kırıklar (boyun kırıklarında: 2. ve 3. metakarp için $15^{\circ}, 4$. metakarp için $40^{\circ}, 5$. metakarp için $60^{\circ}$ ve üzeri açılanma) ile rotasyonel deformite varlığı, cerrahi tedavi için bilinen endikasyonlardır ve sporcular için de geçerlidir. ${ }^{[55]}$ Dördüncü ve 5. karpometakarpal eklemler daha hareketli olduğu için, 4. ve 5. parmaklar açılanmayı daha iyi tolere eder. Bazı yazarlar $70^{\circ}$ 'ye kadar açılanmayı kabul etse de, $30^{\circ}$ üzerindeki açılanmalar

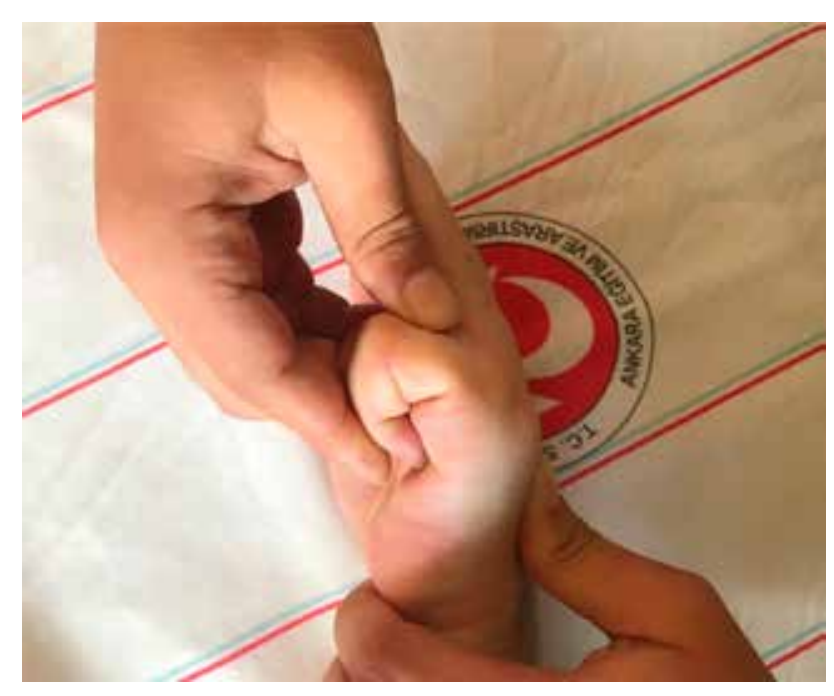

Şekil 7. Jahss manevrası.

parmak hareketini bozabilir ve fleksör dijiti miniminin kuvvetini azaltır. ${ }^{[56,57]} \mathrm{Bu}$ yüzden, $40^{\circ}$ üzerinde olan açılanmalarda düzeltme yapılmalıdır.

Deplase olmuş kırıkların redüksiyonunda Jahss yöntemi tercih edilebilir, MF ve proksimal interfalangeal eklem $90^{\circ}$ fleksiyona alınarak yapılır (Şekil 7). Redüksiyon sonrası stabilite, daha çok korteks parçalanması ve açılanma miktarı ile ilgilidir. Redüksiyon sonrası el bilek $30^{\circ}$ ekstansiyonda, MF eklem 70-90 fleksiyonda, parmaklar nötralde, ulnar oluklu atel ile stabilizasyon sağlanır (Şekil 8). Dördüncü ve 5 . parmaklar birlikte sarılır ve maserasyonu önlemek için aralarına ped/gazlı bez konulur. Tırnak yatağındaki dolaşımı görecek şekilde parmak uçları açıkta bırakılır. 


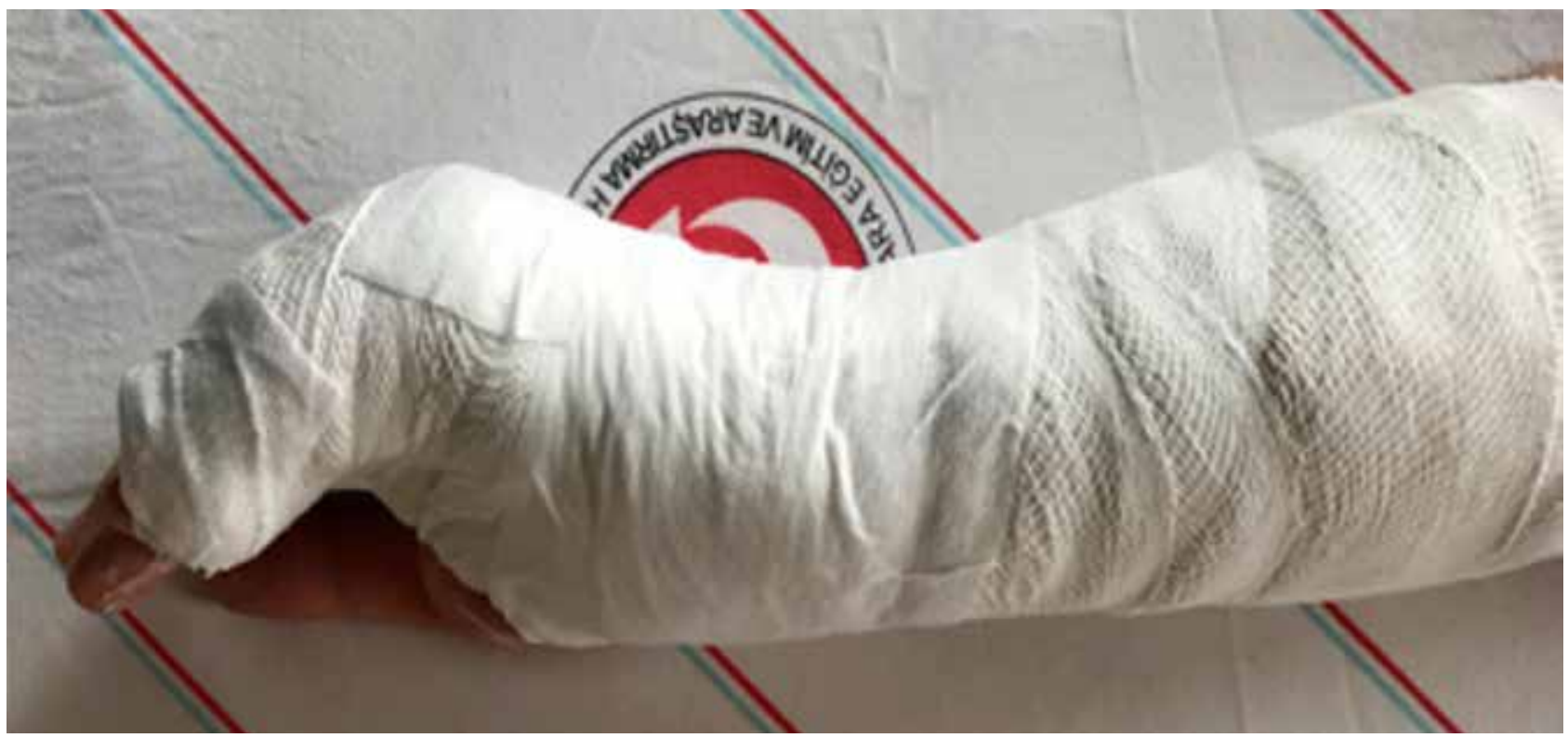

Şekil 8. Boxer alçısı.

Ortalama üç hafta sonunda atel çıkarılır ve parmak egzersizlerine başlanır. Günlük uygulamada en çok rastlanan sorun, ekstansiyonda redüksiyon ve MF eklem tam ekstansiyonda atellemedir. Bu tip tespit, MF eklemlerde kollateral bağ kontraktürüne ve MF eklem sertliğine yol açar. Ancak Hofmeister, atel uygulamasında MF eklemin ekstansiyonda veya fleksiyonda olmasının fonksiyonel sonuçlarda bir fark yaratmadığını göstermiştir. ${ }^{[58]}$ Poolman ise, Cochrane derlemelerini gözden geçirmiş ve herhangi bir atelleme protokolünün üstünlügünü gösterememiştir. ${ }^{[59]}$ Tedavi yöntemine bağlı olmaksızın, olgularda üçüncü ay sonundaki fonksiyonel sonuçlar aslında benzerdir. ${ }^{[60]}$

\section{KAYNAKLAR}

1. Bohm ER, Bubbar V, Hing KY, Dzus A. Above and belowthe-elbow plaster casts for distal forearm fractures in children: a randomized controlled trial. J Bone Joint Surg Am 2006;88(1):1-8. Crossref

2. Webb GR, Galpin RD, Armstrong DG. Comparison of short and long arm plaster casts for displaced fractures in the distal third of the forearm in children. J Bone Joint Surg Am 2006;88(1):9-17. Crossref

3. Alemdaroğlu KB, İltar $S$, Aydoğan $\mathrm{NH}$, Say $\mathrm{F}$, Kılınç $\mathrm{CY}$, Tiftikçi $U$. Three-point index in predicting redisplacement of extra-articular distal radial fractures in adults. Injury 2010;41(2):197-203. Crossref

4. iltar S, Alemdaroğlu KB, Say F, Aydoğan NH. The value of the three-point index in predicting redisplacement of diaphyseal fractures of the forearm in children. Bone Joint J 2013;95$B(4): 563-7$. Crossref
5. Fernandez DL. Closed manipulation and casting of distal radius fractures. Hand Clin 2005;21(3):307-16. Crossref

6. Slutsky DJ, Osterman AL. Fractures and Injuries of the Distal Radius and Carpus: the Cutting Edge. Philadelphia, PA: Elsevier Health Sciences; 2008.

7. Ilyas AM, Jupiter JB. Distal radius fractures -classification of treatment and indications for surgery. Hand Clin 2010;26(1):37-42. Crossref

8. Wulf CA, Ackerman DB, Rizzo M. Contemporary evaluation and treatment of distal radius fractures. Hand Clin 2007;23(2):209-26. Crossref

9. Liporace FA, Adams MR, Capo JT, Koval KJ.. Distal radius fractures. J Orthop Trauma 2009;23(10):739-48. Crossref

10. Merrell GA, Truluck W. Nonoperative Radius Fractures, in Principles and Practice of Wrist Surgery. Philadelphia: Saunders Elsevier; 2010. p.81-8.

11. Prommersberger KJ, Pillukat T. Distal Radius Fractures. In: Ring DC, Cohen MS, editors. Fractures of the Hand and Wrist. US: CRC Press; 2007. p.137-188.

12. Kapoor $\mathrm{H}$, Agarwal A, Dhaon B. Displaced intra-articular fractures of distal radius: a comparative evaluation of results following closed reduction, external fixation and open reduction with internal fixation. Injury 2000;31(2):75-9. Crossref

13. Malviya A, Tsintzas D, Mahawar K, Bache CE, Glithero PR. Gap index: a good predictor of failure of plaster cast in distal third radius fractures. J Pediatr Orthop B 2007;16(1):48-52. Crossref

14. Fernandez DL, Martin CJ. Classification and conservative treatment of distal radius fractures. In: Watson HK, Weinzweig J, editors. The Wrist. Philadelphia: Lippincott Williams \& Wilkins; 2001. p.277-98.

15. Chess D, Hyndman JC, Leahey JL, Brown DCS, Sinclair AM. Short arm plaster cast for distal pediatric forearm fractures. J Pediatr Orthop 1994;14(2):211-3. Crossref 
16. Bhatia $\mathrm{M}$, Housden $\mathrm{PH}$. Redisplacement of paediatric forearm fractures: Role of plaster moulding and padding. Injury 2006;37(3):259-68. Crossref

17. Alemdaroglu KB, illtar S, Çimen O, Uysal M, Alagöz E, Atlıhan $D$. Risk factors in redisplacement of distal radial fractures in children. J Bone Joint Surg Am 2008;90(6):1224-30. Crossref

18. Hang JR, Hutchinson AF, Hau RC. Risk factors associated with loss of position after closed reduction of distal radial fractures in children. J Pediatr Orthop 2011;31(5):501-6. Crossref

19. Devalia KL, Asaad SS, Kakkar R. Risk of redisplacement after first successful reduction in paediatric distal radius fractures: sensitivity assessment of casting indices. J Pediatr Orthop B 2011;20(6):376-81. Crossref

20. Marcheix PS, Peyrou P, Longis B, Moulies D, Fourcade L. Dorsal distal radius fractures in children: role of plaster in redisplacement of these fractures. J Pediatr Orthop B 2011;20(6):372-5. Crossref

21. Flynn JM, Skaggs DL, Waters PM, editors. Rockwood and Wilkins' fractures in children Philadelphia, PA: Lippincott Williams \& Wilkins; 2014.

22. Moss JP, Bynum DK. Diaphyseal fractures of the radius and ulna in adults. Hand Clin 2007;23(2):143-51. Crossref

23. Schemitsch E, Richards R. The effect of malunion on functional outcome after plate fixation of. J Bone Joint Surg Am 1992;74(7):1068-78. Crossref

24. Dumont C, Thalmann R, Macy J. The effect of rotational malunion of the radius and the ulna on supination and pronation: an experimental investigation. B Joint J 2002;84$B(7): 1070-4$. Crossref

25. Hertel R, Rothenfluh DA. Fractures and dislocations of the elbow. In: Bucholz RW, Heckman JD, Court-Brown CM, editors. Rockwood \& Green's Fractures in Adults, 6th ed. Philadelphia: Lippincott Williams \& Wilkins; 2006.

26. Müller ME, Nazarian S, Koch P, Schatzker J.. The Comprehensive Classification of Fractures of Long Bones, 1st ed. Berlin Heidelberg: Springer-Verlag; 2009. Crossref

27. Matthews LS, Kaufer H, Garver DF, Sonstegard DA. The effect on supination-pronation of angular malalignment of fractures of both bones of the forearm. J Bone Joint Surg Am 1982;64(1):14-7. Crossref

28. Uludag A, Tosun HB, Serbest S. Erişkin Radius ve Ulna Kırıkları. Adıyaman Üniv Sağlık Bilim Derg 2015;1(2):111-21.

29. Kasten P, Krefft M, Hesselbach J, Weinberg AM. How does torsional deformity of the radial shaft influence the rotation of the forearm?: a biomechanical study. J Orthop Trauma 2003;17(1):57-60. Crossref

30. Russe O. Fracture of the carpal navicular: diagnosis, nonoperative treatment, and operative treatment. J Bone Joint Surg Am 1960;42(5):759-68. Crossref

31. Herbert TJ, Fisher WE. Management of the fractured scaphoid using a new bone screw. J Bone Joint Surg Br 1984;66$B(1): 114-23$. Crossref

32. Sendher R, Ladd AL. The scaphoid. Orthop Clin North Am 2013;44(1):107-20. Crossref

33. Wolf JM, Dawson L, Mountcastle SB, Owens BD. The incidence of scaphoid fracture in a military population. Injury 2009;40(12):1316-9. Crossref

34. Van Tassel DC, Owens BD, WolfJM. Incidence estimates and demographics of scaphoid fracture in the US population. J Hand Surg 2010;35(8):1242-5. Crossref
35. Ring $\mathrm{D}$, Jupiter $\mathrm{J} B$, Herndon $\mathrm{JH}$. Acute fractures of the scaphoid. J Am Acad Orthop Surg 2000;8(4):225-31. Crossref

36. Adams JE, Steinmann SP. Acute scaphoid fractures. Orthop Clin North Am 2007;38(2):229-35. Crossref

37. Cooney W, Dobyns JH, Linscheid RL. Fractures of the scaphoid: a rational approach to management. Clin Orthop Relat Res 1980;(149):90-7. Crossref

38. Gelberman RH, Menon J. The vascularity of the scaphoid bone. J Hand Surg 1980;5(5):508-13. Crossref

39. Freedman DM, Botte MJ, Gelberman RH. Vascularity of the Carpus. Clin Orthop Relat Res 2001;383:47-59. Crossref

40. Slade JF, Grauer JN, Mahoney JD. Arthroscopic reduction and percutaneous fixation of scaphoid fractures with a novel dorsal technique. Orthop Clin North Am 2001;32(2):24761. Crossref

41. Cooney W 3rd. Scaphoid fractures: current treatments and techniques. Inst Course Lect 2003;52:197-208.

42. Dias J, Wildin CJ, Bhowal B, Thompson JR. Should acute scaphoid fractures be fixed?: a randomized controlled trial. J Bone Joint Surg Am 2005;87(10):2160-8.

43. Buijze GA, et al. Surgical compared with conservative treatment for acute nondisplaced or minimally displaced scaphoid fractures: a systematic review and meta-analysis of randomized controlled trials. J Bone Joint Surg Am 2010;92(6):1534-44. Crossref

44. Herbert T, Fisher W, Leicester A. The Herbert bone screw: a ten year perspective. J Hand Surg 1992;17(4):415-9. Crossref

45. Krimmer $\mathrm{H}$. Management of acute fractures and nonunions of the proximal pole of the scaphoid. J Hand Surg 2002;27(3):245-8. Crossref

46. Gellman H, Caputo RJ, Carter V, Aboulafia A, McKay M. Comparison of short and long thumb-spica casts for nondisplaced fractures of the carpal scaphoid. J Bone Joint Surg Am 1989;71(3):354-7. Crossref

47. Vinnars B, Pietreanu M, Bodestedt $\AA$, af Ekenstam F, Gerdin $B$. Nonoperative compared with operative treatment of acute scaphoid fractures: a randomized clinical trial. J Bone Joint Surg Am 2008;90(6):1176-85. Crossref

48. Barton NJ. Twenty questions about scaphoid fractures. J Hand Surg 1992;17(3):289-310. Crossref

49. Böhler L, Trojan E, Jahna $H$. The results of treatment of 734 fresh, simple fractures of the scaphoid. J Hand Surg 2003;28(4):319-31. Crossref

50. Trojan E. Der Kahnbeinbruch der hand. In: Habilitationschrift. Wien: Eigenverlag \& Bruck Brüder Hollinek, 1961.

51. Clay N, Dias IJ, Costigan PS, Gregg PJ, Barton NJ. Need the thumb be immobilized in scaphoid fractures. J Bone Joint Surg B 1991;73-B(5):828-32. Crossref

52. American Society for Surgery of the Hand. Light TR, editor. Hand Surgery Update 2. American Academy of Orthopaedic Surgeons; 1999.

53. Morgan WJ, Slowman LS. Acute hand and wrist injuries in athletes: evaluation and management. J Am Acad Orthop Surg 2001;9(6):389-400. Crossref

54. Rettig AC. Athletic injuries of the wrist and hand. Am J Sports Med 2003;31(6):1038-48. Crossref

55. Day CS, Stern PJ. Fractures of the metacarpals and phalanges. In: Wolf SW, Hotchkiss RN, Pederson WC, Kozin SH, editors. Green's operative hand surgery, 6th ed. Philadelphia: Elsevier Churchill Livingstone; 2011. p.239-41. 
56. Ali A, Hamman J, Mass DP. The biomechanical effects of angulated boxer's fractures. J Hand Surg 1999;24(4):835-44. Crossref

57. Leung YL, Beredjiklian PK, Monaghan BA, Bozentka DJ. Radiographic assessment of small finger metacarpal neck fractures. J Hand Surg 2002;27(3):443-8. Crossref

58. Hofmeister EP, Kim J, Shin AY. Comparison of 2 methods of immobilization of fifth metacarpal neck fractures: a prospective randomized study. J Hand Surg 2008;33(8):13628. Crossref
59. Poolman RW, Goslings JC, Lee J, Muller MS, Steller EP, Struijs PAA. Conservative treatment for closed fifth (small finger) metacarpal neck fractures. The Cochrane Database of Systematic Reviews; 2005. Crossref

60. Trumble T, Cornwall R, Budoff JE. Core Knowledge in Orthopaedics: Hand, Elbow \& Shoulder, 1st ed. 2006: Mosby. 